\title{
Editorial: changing views on Empire and Imperialism
}

\author{
H. L. WES S E L IN G \\ Department of History, Leiden University, PO Box 9515, 2300 RA Leiden, \\ The Netherlands
}

Words can be confusing and titles can be misleading, particularly if titles consist of one simple word. Two titles suffice to illustrate this phenomenon. In 2000, a book appeared with the title Empire and in 2002 another book appeared with exactly the same title. In the first Empire, Michael Hardt, an American literary theorist, and Antonio Negri, an Italian political philosopher, argued that although classical imperialism is over, Empire is alive and well, albeit in a new form. For them 'Empire' means the following: 'Our basic hypothesis is that sovereignty has taken a new form, composed of a series of national and supranational organisms united under a single logic of rule. This new global form of sovereignty is what we call Empire.' ${ }^{1,2}$ This is a rather special definition of Empire because what one usually has in mind when using that word is something very different. It is the Empire that the other book, written by the British historian Niall Ferguson, is about. This book describes, as the subtitle indicates, The Rise and Demise of the British World Order. But it is also about something more, as is apparent from the rest of the subtitle: and the Lessons for Global Power. These lessons are intended for the rulers of the Empire of today, the Americans. While the first Empire is the Bible for anti-globalists, Ferguson's book can be considered as the New Testament of the advocates of America's imperial ambitions.

The two books clearly indicate that the word 'Empire' means different things for different people, and has very different moral connotations. For Hardt and Negri, Empire is bad; for Ferguson, it is good. This is even truer of words such as imperialism and colonialism, which refer to different phenomena that have been interpreted and appreciated in very different ways. From the very beginning the word imperialism has had unpleasant connotations. Hobson, who published his Imperialism: A Study, in 1902, was very critical of European and, in particular, British imperialism. So were the other authors who used the term to describe the exploitation of the overseas world by Western - in the first instance European - 
powers. The same is true for the word 'colonialism' coined somewhat later by the French socialist Paul Louis, in 1905.

Authors such as Hobson and Louis however were in a minority. While there have always been critics of certain abuses of colonial rule and European expansion, generally speaking the colonial systems were seen as beneficial for the colonized peoples. Lord Lugard, the famous British colonial administrator, was so strongly convinced of the benefits of British colonial rule that he even felt obliged to warn his readers that they should not believe that British penetration into Africa was taking place only to bring civilization, peace, and good government there. 'However greatly such objects may weigh with a large and powerful section of the nation,' he wrote in 1893, 'I do not believe that in these days our national policy is based on motives of philanthropy only'. And he continued: 'it is well, then, to realize that it is for our advantage - and not alone at the dictates of duty - that we have undertaken responsibilities in [...] Africa'. ${ }^{3}$ Please note the phrases 'not only' and 'not alone'. Who would believe today that colonialism had philanthropy as its sole motive?

The moral justification of colonial rule was strengthened by the introduction of modern colonialism, which aimed at economically developing the tropical colonies rather than simply taking away their products. This new policy was introduced in the last quarter of the 19th century. The French called it the "mise en valeur' of the colonies. In the Netherlands Indies it was known as the 'ethical policy'. The Dutch politician Abraham Kuyper - founder of the oldest political party in the Netherlands - wrote in 1878 in the party's manifesto that the policy of exploitation should make way for 'policies of ethical obligation'. What Kuyper had in mind was a kind of guardianship, whereby the Dutch guardian would bring up the Indonesian people, uplift them morally, and later - 'God willing' - give them a more independent position. The Dutch liberal journalist P. Brooshooft used the same metaphor when he spoke of the Indonesians as a 'childish people' needful of protection. An Indonesian critic asked whether the Netherlands would also teach its children to stand on their own two feet! While earlier forms of European colonialism (the Atlantic slave trade, the Dutch cultivation system in Indonesia, the atrocities in Leopold II's Congo Free State) had given rise to criticisms and moral outcries of concerned Europeans, the new colonialism was defended with ethical arguments, thus giving the colonizer a good conscience.

This tendency became even stronger after the First World War, when President Wilson and comrade Lenin formulated their anti-colonial messages. The Europeans were, and remained, convinced of the rightness of what they were doing. In the 1930s, the famous historian Gabriel Hanotaux - who in the 1890s had been France's minister for the Colonies and, later, for Foreign Affairs - edited a large five-volume history of the French colonies in which, among other things he wrote: 'By occupying Algiers France fulfilled the mission that Providence and 
History had entrusted to her. And this was another of those beautiful French adventures: the attraction of the unknown, the pleasures of taking risks, of sacrifices, of showing individual courage, disinterested devotion, the elan of a generous and educative creation. What a generous conquest: not one merchant involved!'4

Not surprisingly, this attitude changed with decolonization. In Asia, decolonization came earlier than in Africa and, already in the 1950s, a critical reassessment of colonialism was taking place. As far as Africa was concerned, the good conscience of the colonizer was still alive and well around 1960. When in that year the Belgian Congo became independent, the Belgian King Baudouin, said at the ceremonial transfer of power:

The independence of the Congo constitutes the end of an enterprise conceived by the genius of King Leopold II. He undertook it with tenacious courage, and it was subsequently continued with perseverance by Belgium [...]. During the past 80 years Belgium has sent the best of its sons to your land [...]. When Leopold II undertook this great work - today finding its crowning achievement - he did not present himself as a conqueror before you, but as a civilizer. The Congo has been endowed with railways, roads, sea lanes, and airways, which, in bringing your peoples into contact with one another, have stimulated unity and have opened your country to the wider dimension of the world. A medical service requiring years to perfect, has been patiently organized, delivering you from manifold dangerous diseases [...]. We are happy therefore, to have given the Congo - in face of the greatest difficulties - those elements indispensable for the structure of a country that has started on the march along the path of development. $^{5}$

Here, of course, the former colonial master was speaking. But not so long before, a Congolese politician had written similar things:

With a most sincere and humanitarian idealism, Belgium came to our aid, and with the support of vigorous native troops she eventually chased away the enemy [the slavers, W.]; she checked the spread of disease [sleeping sickness, W.], instructed us, banned those of our customs that to some extent were inhuman, made us free, happy, vigorous, civilized [...]. All really human and rational men must express their gratitude and bow with respect before this grandiose task, realized in this country at the expense of incalculable material and human sacrifice.

This Congolese author was nobody less than Patrice Lumumba, the first Prime Minister of the independent Republic Congo. ${ }^{6}$

In that new role and on the same occasion as King Baudouin, Lumumba expressed himself however rather differently. He said:

So far as our lot was concerned during the 80 years of the colonialist regime, our wounds are still too fresh and painful to be forgotten [...]. We were quite aware that the law of the state was never the same for a black as for a white, cruel 
and inhuman to the one, accommodating to the other [...]. We knew that in the towns there were magnificent houses for the whites and ramshackle straw huts for the blacks; that a black was admitted neither into cinemas, restaurants, nor shops, labeled with a sign inscribed 'Europeans only'; that a black traveled at the bottom of the ship or at the feet of the white in his luxury cabin [...]. All that, my brothers [...] we have deeply suffered. But all this - all that I have described above - all of it, has now ended. ${ }^{7}$

After decolonization this vision became the new orthodoxy: colonialism was wrong. Thus the appreciation changed but the interpretation remained the same: colonialism had had a strong impact on the non-Western world, a bad influence according to the new school, a good one according to the old one. Later on, a new interpretation also became apparent. It was now argued that Western influence had not been so influential after all. The few centuries of Western dominance in Asia had not had much impact on these old and well-established civilizations. In addition, as far as Africa was concerned, European colonial rule had been a matter of only a few decades, not even a full century. While thus the impact of colonial rule was minimized, at the same time other theorists argued that decolonization had not brought an end to Western dominance. This had been continued in a new form and the dependence of the former colonies on the West had become even stronger. First, this interpretation was called neocolonialism or dependency. In the present-day it is known as globalization.

Here, as is always the case with history writing, the impact of the present on the interpretation of the past is clearly visible. Under colonialism, colonial rule was mostly seen as benevolent and good for the colonized. After decolonization, colonial rule was blamed for the backwardness of what was then called 'the third world'. In recent years opinions have changed again. The Arabic world is now often seen as a world of fundamentalism, terrorism and backwardness, Africa as a world of despotism, civil war and starvation. Former colonial rule, it is heard, cannot be held responsible, or at least not alone responsible, for this sorry state of affairs. The British Empire, Niall Ferguson argues in his book on Empire, is nothing to be ashamed of. On the contrary, it has been beneficial for the world.

There is of course no question that the age of the British Empire has been over for a long time. If today there is an empire at all, it is the American Empire. As far as rhetoric is concerned there seems to be a remarkable continuity between the two. When the British commander General F. S. Maude occupied Baghdad in 1917 he said to the people of Mesopotamia, as it then was:

Our armies do not come into your cities and lands as conquerors or enemies, but as liberators [...]. It is [not] the wish of [our] government to impose upon you alien institutions. [It is our wish] that you should prosper even as in the past, when your lands were fertile, when your ancestors gave to the world literature, science 
and art, and when Baghdad city was one of the wonders of the world. It is [our] hope $[\ldots]$ that once again the people of Baghdad shall flourish. ${ }^{8}$

As Niall Ferguson has observed, President George W. Bush, addressed the people of Iraq, as it now is, in a very similar way in a television speech of 4 April 2003, where he said:

The government of Iraq, and the future of your country, will soon belong to you [...]. We will end a brutal regime [...] so that Iraqis can live in security. We will respect your great religious traditions, whose principles of equality and compassion are essential to Iraq's future. We will help you build a peaceful and representative government that protects the rights of all citizens [...]. You are a good and gifted people - the heirs of a great civilization that contributes to all humanity. ${ }^{9}$

One commentator called this 'Democratic Imperialism', a somewhat contradictory concept. But the history of the word 'imperialism' shows so many variations that a new one can easily find its place.

\section{References}

1. M. Hardt and A. Negri (2000) Empire (Cambridge, MA) p. XII.

2. N. Ferguson (2002) Empire. The Rise and Demise of the British World Order and the Lessons for Global Power (London: Allen Lane).

3. R. Faber (1966) The Vision and the Need. Late Victorian Imperialist Aims (London) p. 121.

4. G. Hanotaux (1933) Pour l'empire colonial français (Paris) p. 41.

5. P. C. Emmer and H. L. Wesseling (eds) (1979) Reappraisals in Overseas History (Leiden) p. 172.

6. P. C. Emmer and H. L. Wesseling (eds) (1979) Reappraisals in Overseas History (Leiden) p. 166, note 8.

7. P. C. Emmer and H. L. Wesseling (eds) (1979) Reappraisals in Overseas History (Leiden) p. 172.

8. N. Ferguson (2003) Hegemony or Empire?, Foreign Affairs, September/October, p. 154.

9. N. Ferguson (2003) Hegemony or Empire?, Foreign Affairs, September/October, p. 154. 
